AGRITECH, Vol. 37, No. 4, November 2017, Hal. 471-476

DOI: http://doi.org/10.22146/agritech.12720

ISSN 0216-0455 (Print), ISSN 2527-3825 (Online)

Tersedia online di https://jurnal.ugm.ac.id/agritech/

\title{
Diskriminasi Kopi Lanang Menggunakan UV-Visible Spectroscopy dan Metode SIMCA
}

\author{
Discrimination of Peaberry Coffee using UV-Visible Spectroscopy and SIMCA Method \\ Diding Suhandy*, Meinilwita Yulia², Yuichi Ogawa ${ }^{3}$, Naoshi Kondo ${ }^{3}$ \\ ${ }^{1}$ Laboratorium Rekayasa Bioproses dan Pasca Panen, Jurusan Teknik Pertanian, Universitas Lampung, \\ Jl. Soemantri Brojonegoro No. 1 Gedong Meneng Bandar Lampung, Lampung 35145, Indonesia, \\ ${ }^{2}$ Jurusan Teknologi Pertanian, Politeknik Negeri Lampung, \\ Jl. Soekarno Hatta No. 10, Rajabasa Bandar Lampung, Lampung, Indonesia \\ ${ }^{3}$ Laboratorium Bio-Sensing Engineering, Sekolah Pasca Sarjana Pertanian, Universitas Kyoto, \\ Sakyo ku, Kyoto 606-8502, Jepang \\ Email: diding.sughandy@ffp.unila.ac.id
}

Submisi: 22 Agustus 2016; Penerimaan: 18 Juli 2017

\begin{abstract}
ABSTRAK
Pada penelitian ini kami menggunakan informasi yang terdapat dalam spektra ultraviolet-visible dari sampel larutan kopi pada panjang gelombang 190-700 nm untuk mengklasifikasi dua jenis kopi yaitu kopi lanang dan kopi biasa (kopi bukan lanang). Spektra kedua jenis kopi tersebut diambil menggunakan alat UV-Vis/NIR spektrometer (JASCO Corp., Tokyo, Jepang). Metode analisis data berpeubah banyak bernama SIMCA digunakan untuk membangun model klasifikasi jenis kopi dengan cara membangun model PCA pada setiap kelas yaitu kelas kopi lanang dan kelas kopi biasa. Model SIMCA yang dibangun kemudian digunakan untuk mengevaluasi apakah sebuah sampel termasuk ke dalam kelas tertentu atau termasuk ke dalam lebih dari satu kelas. Kualitas model klasifikasi kemudian dievaluasi menggunakan parameter accuracy, sensitivity dan specificity. Pada penelitian ini, hasil klasifikasi menggunakan model SIMCA menunjukkan bahwa proses diskriminasi kopi lanang dan kopi biasa menghasilkan nilai accuracy, sensitivity dan specificity yang sangat memuaskan. Hasil riset ini telah membuka kemungkinan pengembangan metode yang mudah dan cepat berbasis spektra $U V$-visible untuk proses uji keaslian kopi lanang.
\end{abstract}

Kata kunci: Model klasifikasi; diskriminasi; kopi lanang; SIMCA; UV-Visible spectroscopy

\begin{abstract}
In this research, the use of ultraviolet-visible (UV-VIS) spectral information of coffee solution in the range of 190$700 \mathrm{~nm}$ to classify the type of coffee into lanang and regular. The spectral data of lanang and regular coffee were acquired using UV-Vis/NIR spectrometer (JASCO Corp., Tokyo, Japan). The multivariate data analysis method, SIMCA, was used to construct the classification models which worked with the individual PCA model for each class of coffee samples. SIMCA provided the classification of the samples into one or more classes. The performance of the developed SIMCA model for each class was then evaluated in terms of its sensitivity, specificity, and accuracy. The SIMCA classification method showed that it was possible to discriminate and separate the samples into two different classes (lanang and regular coffee) satisfactory value of accuracy, sensitivity and specificity. This result could open a development of a rapid and reliable method based on UV-Vis spectra for the authentication of lanang coffee in the near future.
\end{abstract}

Keywords: Classification model; discrimination; peaberry coffee; SIMCA; UV-Visible spectroscopy 


\section{PENDAHULUAN}

Indonesia saat ini adalah negara penghasil kopi terbesar ke-empat di dunia setelah Brasil, Vietnam, dan Kolombia untuk kopi robusta dan arabika (International Coffee Organization, 2016). Selain itu, Indonesia juga dikenal sebagai penghasil beberapa jenis kopi yang memiliki nilai ekonomi tinggi. Selain kopi luwak, Indonesia juga memiliki kopi lanang (peaberry coffee). Kopi lanang merupakan salah satu jenis kopi yang sangat unik. Umumnya kopi berbiji dua (dikotil), namun untuk kopi lanang, biji kopinya hanya satu. Selain itu jumlah produksinya sangat terbatas. Dalam sekali panen saja, kopi ini hasilnya sangat sedikit, perbandingannya dari $50 \mathrm{~kg}$ biji kopi, setelah disortir hanya terdapat $800 \mathrm{~g}$ biji kopi lanang. Prosesnya pun biasanya hanya terjadi secara alami dan tidak dapat direkayasa, selain itu, kopi lanang ini mempunyai citarasa yang lebih tinggi, aromanya pun lebih wangi dan rasanya lebih padat dibandingkan dengan kopi bukan lanang (kopi biasa). Selain itu kopi lanang juga dipercaya oleh sebagian orang dapat meningkatkan vitalitas seksual meskipun hal ini secara ilmiah baru dibuktikan pada hewan mencit (Wahono, 2016). Tentu saja dengan kombinasi rasa yang unik, sugesti akan manfaat kopi lanang dan produksi yang terbatas membuat harga kopi lanang sangat tinggi di pasaran dan bisa mencapai sekitar 300 ribu rupiah per kilogram. Dibandingkan dengan harga kopi bukan lanang atau kopi biasa yang hanya mencapai 50 ribuan rupiah per kilogram membuat kopi lanang menjadi salah satu target pemalsuan atau pengoplosan produk.

Untuk mencegah adanya pemalsuan, sebenarnya tidak sulit membedakan kopi lanang dan kopi bukan lanang. Secara fisik, biji kopi lanang dan kopi bukan lanang (kopi biasa) dapat dibedakan dengan mudah pada bentuk biji baik sebelum maupun sesudah disangrai. Gambar 1 menunjukkan kopi lanang dapat dibedakan dari kopi bukan lanang di mana kopi lanang memiliki bentuk lebih bulat dan ukuran lebih kecil.

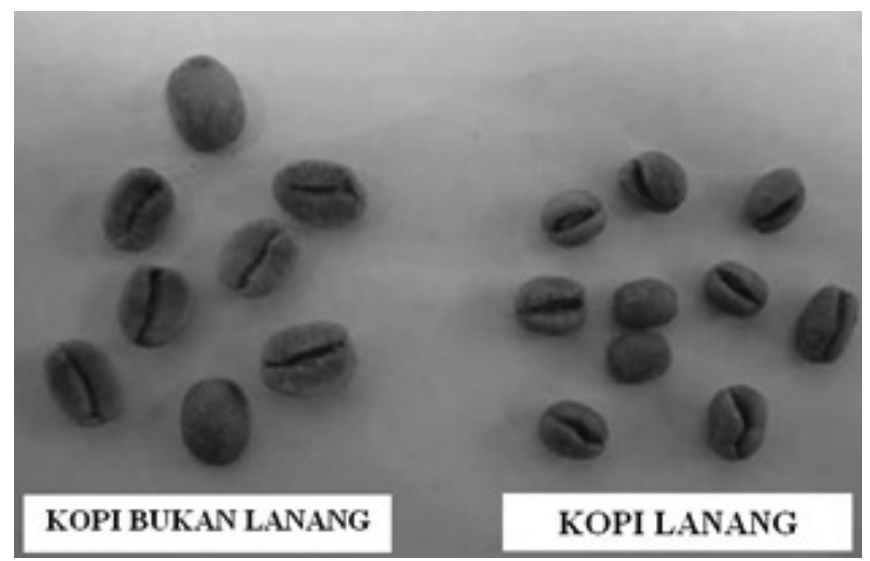

Gambar 1. Perbandingan kopi lanang dan bukan lanang pada bentuk biji (Franca and Oliveira, 2008)
Proses penyangraian hanya mengubah tampilan fisik berupa warna tapi tidak mengubah ukuran sehingga kopi lanang dan kopi bukan lanang tetap bisa dibedakan secara visual ataupun menggunakan metode pengolahan citra (image processing). Namun demikian, proses penggilingan kopi membuat tampilan fisik kopi lanang dan kopi bukan lanang menjadi sulit untuk dibedakan. Untuk membedakan kedua kopi berdasarkan rasa sangat sulit karena hanya dapat dilakukan oleh para ahli kopi dan penilaiannya menjadi subyektif sehingga tidak konsisten. Proses diskriminasi menjadi lebih rumit lagi saat kedua jenis kopi bubuk tersebut dicampur atau dioplos.

Proses pengembangan metode analisis untuk menguji kualitas kopi termasuk proses diskriminasi kopi dan campurannya sudah banyak dilakukan terutama menggunakan metode spectroscopy di daerah infra merah dekat (near infrared atau NIR). Sebagai contoh, Wang dkk. (2009) menggunakan FTIR (Fourier transform infrared) spectroscopy yang terintegrasi dengan metode ATR (attenuated total reflectance) untuk membedakan kopi asli Kona dan kopi bukan Kona. NIR spectroscopy juga digunakan bersama dengan metode analisis genetic algorithm (GA) untuk mendeteksi pencampuran bahan bukan kopi (gandum) ke dalam sampel kopi (Ebrahimi-Najafabadi dkk., 2012). Namun demikian teknik spectroscopy di daerah infra merah dekat melibatkan peralatan berupa spectrometer dan sumber cahaya (light source) yang tidak murah sehingga pengembangannya di Indonesia cukup terkendala. Sementara itu, penggunaan metode analisis berbasis $U V$-Visible spectroscopy telah digunakan untuk proses diskriminasi kopi murni dan kopi yang tercemar bahan bukan kopi seperti kulit buah kopi yang ditambahkan saat proses sangrai (Souto dkk., 2015). Selain itu, UV-Visible spectroscopy berhasil membedakan kopi luwak dan bukan luwak dengan akurasi klasifikasi mencapai 90\% (Suhandy dkk., 2016a). Penggunaan metode analisis berbasis UV-Visible spectroscopy sangat potensial dikembangkan di Indonesia di mana alat yang digunakan merupakan salah satu alat spectroscopy yang sangat terjangkau dan saat ini tersedia hampir di seluruh laboratorium analisis standar. Saat ini analisis $U V$-Visible spectroscopy untuk proses diskriminasi kopi lanang dan bukan lanang belum dilakukan. Sehingga tujuan dari riset ini adalah pertama membangun model diskriminasi menggunakan metode SIMCA dan kedua mengevaluasi model diskriminasi yang dibangun menggunakan metode SIMCA yang mampu mengklasifikan jenis kopi lanang dan kopi bukan lanang.

\section{METODE PENELITIAN}

\section{Sampel Kopi}

Sampel kopi lanang dan kopi biasa (bukan lanang) diambil langsung dari petani kopi di daerah Liwa Provinsi 
Lampung. Untuk memastikan keaslian kopi lanang maka kopi diambil dalam bentuk kopi sangrai utuh dan satu per satu diperiksa berdasarkan tampilan ukuran secara visual. Setelah itu kopi lanang dan kopi biasa digiling menggunakan home-coffee-grinder (Sayota) untuk menghasilkan kopi bubuk. Riset sebelumnya menunjukkan ukuran partikel kopi bubuk berpengaruh terhadap kualitas spektra (Suhandy dkk., 2016b). Pada penelitian ini digunakan ukuran partikel yang sama yaitu $420 \mu \mathrm{m}$ dengan cara mengayak kopi bubuk menggunakan ayakan no. 40 dan diayak selama 10 menit menggunakan mesin pengayak (CSC Scientific Company, Inc. USA). Untuk kopi lanang dipersiapkan 40 sampel dan untuk kopi biasa (bukan lanang) dipersiapkan sebanyak 38 sampel. Selanjutnya sampel kopi lanang dan kopi biasa masing-masing dibagi menjadi dua kelompok yaitu sampel kopi lanang untuk proses pembuatan model SIMCA (training set) sebanyak 20 sampel dan sampel kopi lanang untuk proses pengujian model SIMCA (prediction set) sebanyak 20 sampel kopi lanang. Untuk kopi biasa, 20 sampel untuk pembuatan model SIMCA (training set) dan 18 sampel untuk pengujian model SIMCA (prediction set).

\section{Proses Ekstraksi Sampel Kopi Bubuk}

Pengambilan spektra sampel kopi dilakukan pada bentuk larutan atau seduhan kopi dengan menggunakan proses ekstraksi pada setiap sampel kopi. Prosedur ekstraksi sampel kopi dilakukan dengan mengacu kepada Souto dkk. (2015). Pertama dengan menimbang sebanyak 1 gram dari setiap sampel kopi dan menyeduhnya dengan menambahkan air distilasi sebanyak $10 \mathrm{~mL}$ bersuhu 90-98 ${ }^{\circ} \mathrm{C}$. Seduhan sampel kopi kemudian diaduk menggunakan

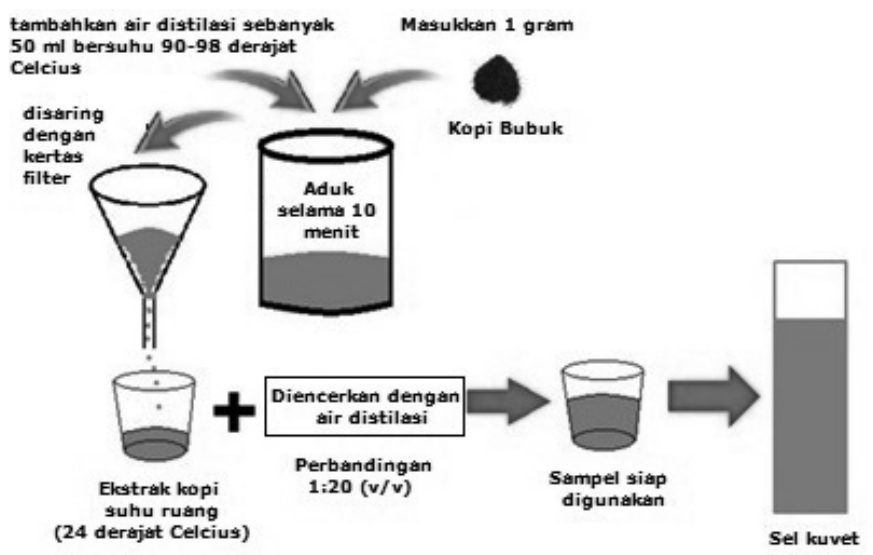

Proses Ekstraksi Kopi

Gambar 2. Proses ekstraksi sampel kopi (mengacu kepada Souto dkk. 2015). pengaduk magnetic selama 5 menit pada kecepatan 350 rpm (Cimarec ${ }^{\mathrm{TM}}$ Stirrers, Barnstead International, USA). Setelah itu seduhan sampel kopi disaring menggunakan kertas filter Whatmann No 40. Hasil saringan seduhan sampel kopi didiamkan untuk mencapai suhu ruang dan kemudian diencerkan menggunakan air distilasi dengan perbandingan 1:20 (volume/volume). Hasil pengenceran ini kemudian siap untuk diambil spektranya. Secara lengkap proses ekstraksi sampel kopi dapat dilihat pada Gambar 2.

\section{Pengambilan Spektra}

Pengambilan spektra sampel larutan kopi yang sudah disaring dan diencerkan dilakukan dengan menggunakan spectrometer V670 type UV-VIS/NIR spectrometer (JASCO Corp., Tokyo, Japan). Spektrometer ini memiliki dua buah detektor yaitu PMT (photomultiplier tubes) untuk daerah $U V$-Visible dan detektor berbahan timbal sulfida $(\mathrm{PbS})$ untuk daerah inframerah dekat (NIR). Sebanyak $3 \mathrm{~mL}$ sampel larutan kopi diteteskan ke dalam sel kuvet dengan tebal $10 \mathrm{~mm}$. Setiap sampel diambil spektranya pada panjang gelombang 190-700 nm dengan lebar pita (bandwidth) sebesar $1 \mathrm{~nm}$ dengan kecepatan scanning $400 \mathrm{~nm} / \mathrm{menit}$. Untuk referensi digunakan air distilasi dan diambil sebelum pengambilan spektra sampel. Seluruh proses pengambilan spektra dikontrol menggunakan perangkat lunak The Spectra Manager untuk windows (JASCO Spectral Manager, JASCO Corp., Tokyo, Japan).

\section{Proses Klasifikasi dengan Menggunakan Metode SIMCA}

SIMCA (soft independent modelling of class analogies) merupakan salah satu metode klasifikasi berbasis data terbimbing (supervised data classification). SIMCA memiliki dua kelompok sampel. Kelompok pertama adalah sampel untuk membangun model SIMCA yang disebut sebagai sampel training (training set). Setiap kelas (kopi lanang dan kopi biasa) memiliki sampel training masing-masing dan digunakan untuk membangun model SIMCA kopi lanang dan model SIMCA kopi biasa. Kelompok kedua adalah sampel prediksi (prediction set) yang akan digunakan untuk mengevaluasi kemampuan model SIMCA yang dibangun untuk mengklasifikasi sampel kopi sesuai dengan kelasnya yaitu kopi lanang atau kopi biasa. Pada prosesnya, SIMCA menggunakan nilai standar deviasi residual sebagai ukuran atau kriteria untuk proses pengkelasan sampel. Sehingga setiap kelas akan memiliki model SIMCA tertentu dengan memiliki nilai batas berupa nilai standar deviasi residual tertentu sebagai panduan untuk mengevaluasi apakah sebuah sampel yang akan dievaluasi kelasnya termasuk ke dalam kelas tertentu atau tidak. Jika sampel tersebut memiliki nilai residual di bawah nilai batas model SIMCA maka sampel 
tersebut dikelompokkan ke dalam kelas tersebut dan jika nilai residualnya lebih tinggi maka sampel tersebut berada di luar kelas. Untuk perangkat lunak pengolah data multivariate (PCA dan SIMCA) digunakan The Unscrambler ${ }^{\circledR}$ versi. 9.7 (Camo, Norwegia).

\section{HASIL DAN PEMBAHASAN}

\section{Analisis Spektra Original Sampel Kopi}

Gambar 3 menunjukkan spektra original (yaitu spektra tanpa pengolahan yang diperoleh secara langsung dari hasil pengukuran alat spektrometer) sampel kopi lanang dan kopi biasa (bukan lanang) pada panjang gelombang 190-700 nm. Pertama terlihat sulit untuk membedakan kedua jenis kopi lanang dan kopi biasa di mana kedua jenis kopi memiliki bentuk spektra yang sangat identik. Kedua, pada beberapa puncak (peak) dan lembah dapat terlihat pada spektra sampel kopi. Untuk puncak, terdapat pada panjang gelombang 280 nm (panjang gelombang yang berhubungan dengan absorban kafein) dan panjang gelombang $325 \mathrm{~nm}$ (panjang gelombang yang berhubungan dengan absorban caffeic acid) (Souto dkk., 2015).

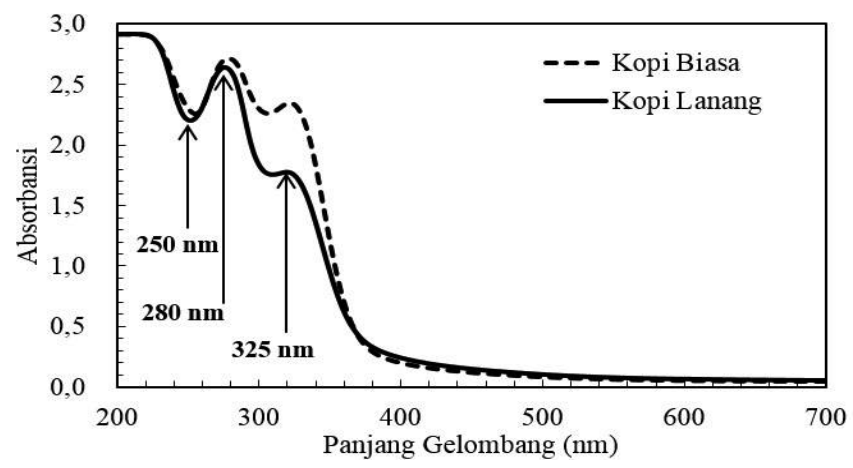

Gambar 3. Spektra original (original spectra) sampel kopi lanang dan kopi biasa (bukan lanang) pada panjang gelombang 190-700 nm

\section{Analisis Komponen Utama (Principal Component Analysis atau PCA)}

Gambar 4 menunjukkan plot dari komponen utama pertama dan kedua $(\mathrm{PC} 1 \times \mathrm{PC} 2)$ hasil analisis $\mathrm{PCA}$ pada spektra original sampel kopi lanang dan kopi biasa di rentang panjang gelombang 190-700 nm. Tampak jelas pada Gambar 4 terdapat perbedaan yang nyata antara kopi lanang $(\times)$ dan kopi biasa (o). Hasil analisis PCA juga menunjukkan bahwa terdapat dua kelas sampel yang berbeda yang dapat dibuat untuk membangun model SIMCA yaitu kelas kopi lanang dan kelas kopi biasa.

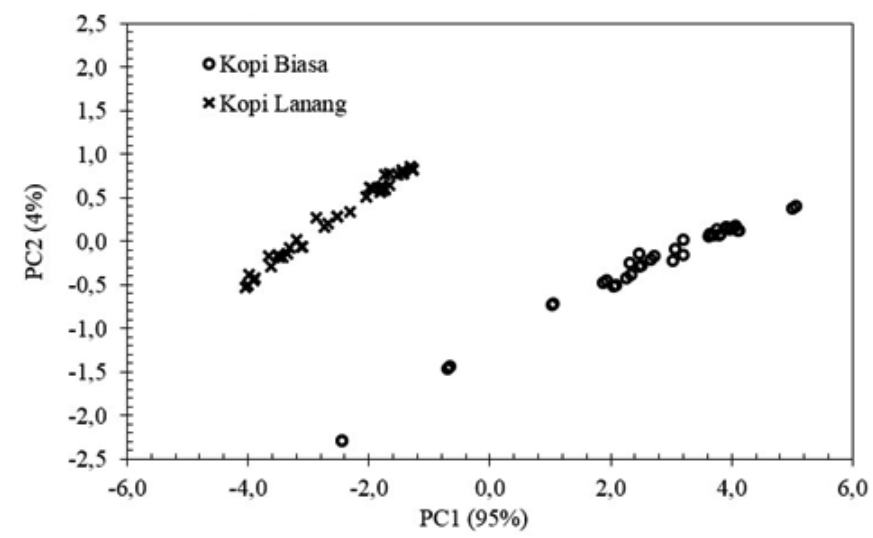

Gambar 4. Scatter plot PC1 dan PC2 untuk seluruh sampel kopi lanang dan kopi biasa (bukan lanang) dengan menggunakan spektra original $190-700 \mathrm{~nm}$

\section{Hasil Klasifikasi Menggunakan Metode SIMCA}

\section{Plot Cooman's}

Pertama model SIMCA untuk kelas kopi lanang dan kelas kopi biasa dibangun menggunakan sampel training untuk masing-masing kelas dan menggunakan panjang gelombang 190-700 nm. Model ini melibatkan sebanyak 511 peubah panjang gelombang (sebagai prediktor atau peubah $\times$ ). Model SIMCA yang telah dibangun untuk kopi lanang dan kopi biasa kemudian digunakan untuk memprediksi kelas sampel kopi lanang dan kopi biasa pada kelompok sampel prediksi (prediction set). Gambar 5 menunjukkan hasil klasifikasi dalam bentuk plot Cooman's dengan model distance untuk kopi lanang dan kopi biasa dengan keanggotaan kelas pada batas signifikan (significance level) 1\%. Dari Gambar 5 tampak bahwa sampel masing-masing kelas dapat dikelompokkan secara tepat sesuai dengan kelasnya yaitu kelas kopi lanang pada kuadran kanan bawah dan kelas

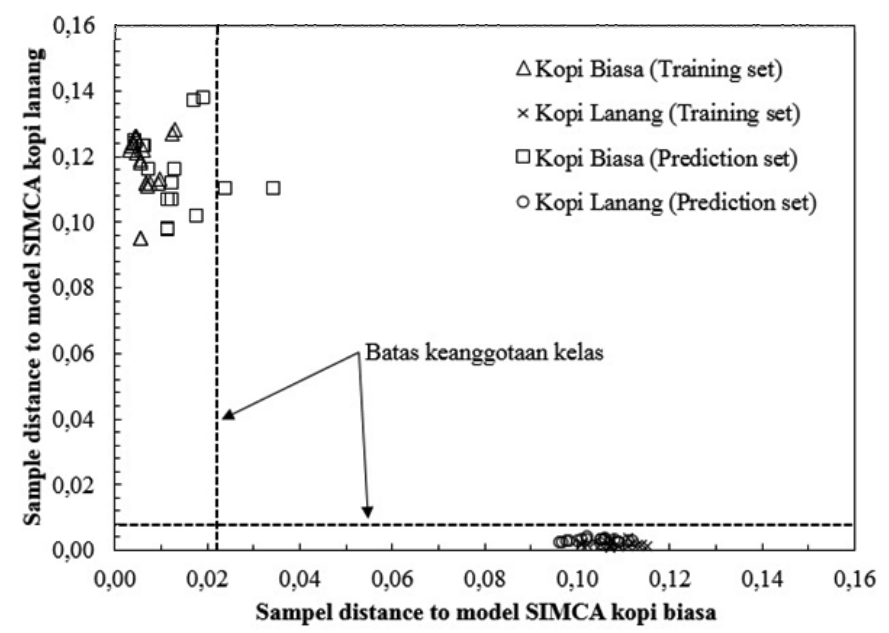

Gambar 5. Plot Cooman's hasil klasifikasi jenis kopi menggunakan model SIMCA untuk kopi lanang dan kopi biasa 
tidak ada satu pun sampel yang masuk ke dalam dua kelas secara bersamaan ditunjukkan dengan tidak ada sampel yang terletak di kuadran kiri bawah. Namun demikian terdapat dua sampel pada kelas kopi biasa yang ternyata tidak termasuk kelas mana pun yang ditunjukkan dengan letak kedua sampel itu di kuadran kanan atas.

\section{Analisis Modelling Power}

Model klasifikasi berupa model SIMCA yang dibangun dan digunakan untuk proses prediksi melibatkan banyak sekali peubah. Pada penelitian ini terdapat 511 peubah panjang gelombang pada rentang 190-700 nm. Untuk melihat kontribusi setiap panjang gelombang terhadap proses klasifikasi maka dapat dilihat menggunakan hasil analisis modelling power. Untuk dikatakan berkontribusi signifikan maka panjang gelombang tersebut harus memiliki nilai modelling power lebih dari 0,3 (Sundaram dkk., 2013; Kumar dkk., 2015). Gambar 6 menunjukkan plot panjang gelombang dengan nilai modelling power pada model SIMCA kopi lanang dan model SIMCA kopi biasa. Dapat dilihat pada model SIMCA kopi lanang seluruh peubah (511 peubah) pada panjang gelombang 190-700 nm memiliki nilai modelling power di atas 0,3. Nilai modelling power pada model SIMCA kopi lanang juga terlihat cukup konsisten dan cukup tinggi di atas 0,9 di rentang 190-700 nm. Untuk model SIMCA kopi biasa nilai modelling power ada yang nilainya di bawah 0,3 yaitu dari 190-215 nm dan 590-700 nm. Pada rentang panjang gelombang tersebut bisa dikatakan kontribusinya tidak signifikan dalam proses klasifikasi kopi biasa. Secara umum nilai modelling power pada model SIMCA kopi biasa cukup tinggi di atas 0,9 namun kemudian terus menurun. Dengan demikian, dapat ditentukan bahwa model SIMCA kopi lanang lebih baik bila dibandingkan dengan model SIMCA kopi biasa dalam proses klasifikasi. Hal ini terlihat pada hasil analisis Cooman's di Gambar 5 di mana model SIMCA kopi lanang dapat sepenuhnya mengklasifikasi secara

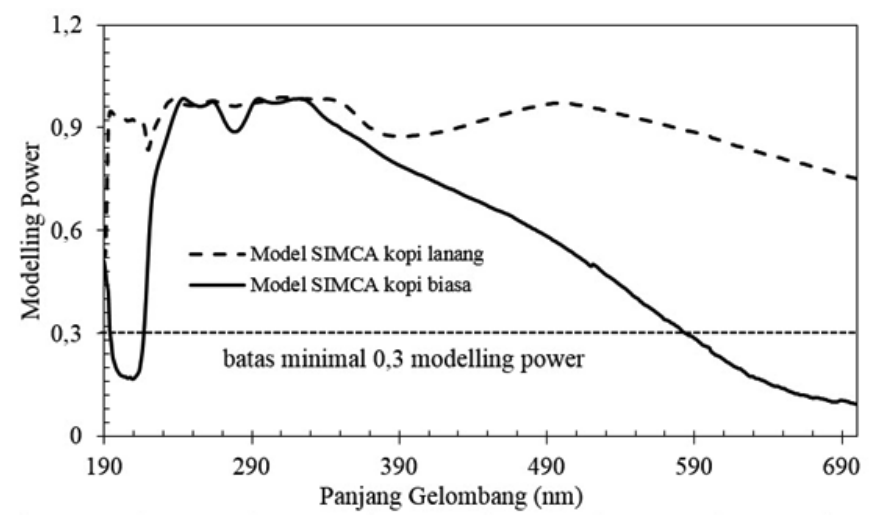

Gambar 6. Plot panjang gelombang dan nilai modelling power pada model SIMCA kopi lanang dan kopi biasa pada panjang gelombang $190-700 \mathrm{~nm}$ benar kopi lanang pada sampel prediksi sesuai kelasnya. Pada model SIMCA kopi biasa terdapat dua sampel pada sampel prediksi yang gagal diklasifikasikan sebagai kopi biasa.

\section{Analisis Confusion Matrix Hasil Klasifikasi}

Tabel 1 menunjukkan data confusion matrix untuk menghitung nilai accuracy, sensitivity dan specificity hasil klasifikasi menggunakan model SIMCA baik untuk kopi lanang maupun kopi biasa (bukan lanang). Untuk perhitungan nilai accuracy, sensitivity, dan specificity mengacu kepada Lavine (2009). Hasil perhitungan menunjukkan model SIMCA yang dibangun baik untuk kopi lanang maupun kopi biasa menghasilkan nilai accuracy, sensitivity dan specificity yang sangat memuaskan (100\% untuk semua parameter). Hasil ini mengindikasikan kemampuan teknik UV-Visible spectroscopy dan metode SIMCA dalam proses diskriminasi kopi lanang dan kopi biasa (bukan lanang).

Tabel 1. Confusion matrix untuk hasil klasifikasi kopi lanang dan kopi biasa dengan nilai accuracy, sensitivity dan specificity

\begin{tabular}{lccc}
\hline & $\begin{array}{c}\text { Model SIMCA } \\
\text { kopi lanang }\end{array}$ & $\begin{array}{c}\text { Model SIMCA } \\
\text { kopi biasa }\end{array}$ \\
\hline Kopi lanang (aktual) & 20 & 0 \\
Kopi biasa (aktual) & 0 & 100 & \\
Accuracy (\%) & & 100 & \\
Sensitivity (\%) & & 100 & \\
Specificity (\%) & & & \\
\hline
\end{tabular}

\section{KESIMPULAN}

Pada penelitian ini dapat disimpulkan bahwa proses klasifikasi kopi lanang dan kopi biasa menggunakan data spektra di daerah $U V$-Vis dan metode SIMCA telah berhasil dilakukan. Model SIMCA kopi lanang berhasil mengkelompokkan seluruh sampel di prediction set ke dalam kelas yang sesuai yaitu kopi lanang. Untuk model SIMCA kopi biasa dari seluruh sampel yang diuji terdapat dua sampel yang tidak berhasil dikelompokkan ke dalam kelasnya yaitu kelas kopi biasa. Untuk evaluasi hasil klasifikasi, performansi kedua model SIMCA kopi lanang dan kopi biasa sangat memuaskan dengan nilai 100\% untuk parameter accuracy, sensitivity dan specificity. Hasil di atas menunjukkan potensi penggunaan metode analisis berbasis $U V$-Visible spectroscopy untuk proses uji keaslian produk kopi lanang yang relatif lebih murah, cepat dan tentu saja bebas limbah kimia karena hanya melibatkan pelarut air distilasi pada proses ekstraksi sampel kopi. 


\section{UCAPAN TERIMA KASIH}

Penulis mengucapkan terima kasih kepada Professor Naoshi Kondo dan Associate Professor Yuichi Ogawa yang telah mengundang penulis dalam program JASSO follow-up research fellowship tahun 2016 di Laboratorium Bio-Sensing Engineering Universitas Kyoto. Penelitian ini dilakukan selama penulis mengikuti program JASSO follow-up research fellowship sebagai guest researcher associate selama 3 bulan (25 Juli-22 Oktober 2016).

\section{DAFTAR PUSTAKA}

Ebrahimi-Najafabadi, H., Leardi, R., Oliveri, P., Casolino, M.C., Jalali-Heravi, M. dan Lanteri, S. (2012). Detection of addition of barley to coffee using near infrared spectroscop yand chemometric techniques. Talanta 99: 175-179.

Franca, A.S. dan Oliveira, L.S. (2008). Chemistry of defective coffee beans. Dalam: Koeffer, E.N. (ed.). Food Chemistry Research Developments, hal 105-138. Nova Science Publishers, Inc.

International Coffee Organization (2016). Total production by all exporting countries. http://www.ico.org/prices/ po-production.pdf. [22 Agustus 2016].

Kumar, S., Panchariya, P.C., Prasad, P.B. dan Sharma, A.L. (2015). Non-destructive classification of Assam black tea using ultra-fast gas chromatography (UFGC) coupled with soft independent modeling of class analogy (SIMCA). Sensors and Transducers 186(3): 104-111.

Lavine, B.K. (2009). Validation of classifiers. Dalam: Walczak, B., Tauler, R. dan Brown, S. (ed.). Comprehensive chemometrics, hal 587-599. Elsevier, Oxford.
Souto, U.T.C.P., Barbosa, M.F., Dantas, H.V., Pontes, A.S., Lyra, W.S., Diniz, P.H.G.D., Araújo, M.C.U. dan Silva, E.C. (2015). Identification of adulteration in ground roasted coffees using UV-Vis spectroscopy and SPALDA. LWT - Food Science and Technology 63(2): 1037-1041.

Suhandy, D., Waluyo, S., Sugianti, C., Yulia, M., Iriani, R., Handayani, F.N. dan Apratiwi, N. (2016a). The feasibility of using ultraviolet-visible spectroscopy and soft independent modelling of class analogies (SIMCA) for classification of Indonesian palm civet coffee (kopi luwak). Prosiding Seminar Nasional Tempe. $28 \mathrm{Mei}$ 2016. Bandar Lampung.

Suhandy, D., Waluyo, S., Sugianti, C., Yulia, M., Iriani, R., Handayani, F.N. dan Apratiwi, N. (2016b). The use of UV-Vis-NIR spectroscopy and chemometrics for identification of adulteration in ground roasted arabica coffees -investigation on the influence of particle size on spectral analysis-. Prosiding Seminar Nasional Tempe. 28 Mei 2016. Bandar Lampung.

Sundaram, J., Park, B., Kwon, Y. dan Lawrence, K.C. (2013). Surface enhanced Raman scattering (SERS) with biopolymer encapsulated silver nanosubstrates for rapid detection of foodborne pathogens. International Journal of Food Microbiology 167: 67-73.

Wahono, B. (2016). Effects of peaberry coffee on the sexual behavior and the blood testosterone levels of the male mouse (mus musculus). Proceeding of $3 \mathrm{rd}$ International Conference on Research, Implementation and Education of Mathematics and Science. 16-17 May 2016. Yogyakarta. Hal. B21-B25.

Wang, J., Jun, S., Bittenbender, H.C., Gautz, L. dan Li, Q.X. (2009). Fourier transform infrared spectroscopy for Kona coffee authentication. Journal of Food Science 74(5): C385-C391. 